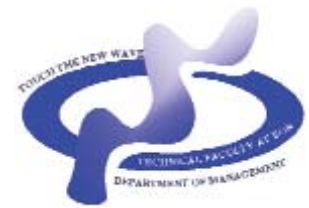

www.sjm06.com
Serbian

Journal

of

Management

\title{
MULTI-CRITERIA RANKING OF THE DANUBE WATER QUALITY ON ITS COURSE THROUGH SERBIA
}

\author{
Ivana Mladenović-Ranisavljevića ${ }^{*}$, Ljiljana Takića, Milovan Vukovićb, \\ Đorđe Nikolićb

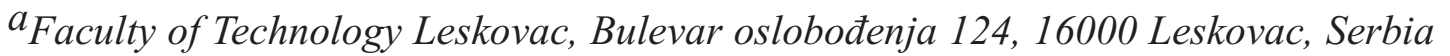

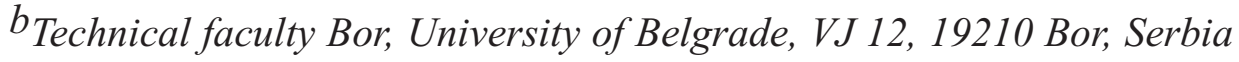 \\ ${ }^{c}$ Faculty of Occupational Safety, Čarnojevića 10a, 18000 Niš, Serbia

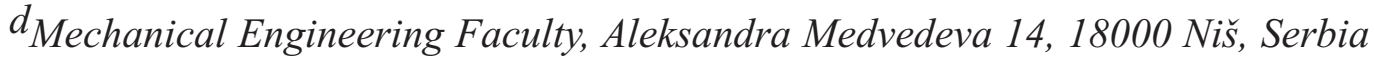

(Received 12 May 2012; accepted 11 September 2012)

\begin{abstract}
This paper presents the results of multi-criteria ranking of the Danube water quality along its course through Serbia by using PROMETHEE/GAIA method. The ranking was based on the values of the water quality parameters measured at eight measuring stations on the Danube River in 2010. For the purposes of the investigation, ten water quality parameters that indicate physical, chemical and microbiological characteristics of water were selected. These parameters are also used in the WQI (Water Quality Index) methodology in determining the overall water quality. The results show that the water quality on the exit profile is better than the quality of the water at the entrance profile.
\end{abstract}

Keywords: the Danube, water quality parameters, PROMETHEE/GAIA method.

\section{INTRODUCTION}

According to the length $(2,857 \mathrm{~km})$, the Danube is the second longest river in Europe, after the Volga. Located in the very heart of central Europe, the Danube River basin represents "the most important non-oceanic water body" which discharges into the Black Sea through wide delta. Around $588 \mathrm{~km}$ of its length belongs to Serbia. The largest tributaries on the territory of Serbia are the Tisa, the Tamiš and the Danube-Tisa-Danube canal on the left, and the Drava, the Sava and the Velika Morava on the right side (ICPDR,

\footnotetext{
*Corresponding author: iva_mlxp@yahoo.com
}

DOI: 10.5937/sjm 7-2549 
2005).

Significant environmental and health risks are associated with water quality and sanitation in Serbia. Also, low-quality surface water poses threats to human health when used for recreation, especially when blue-green algae are present in eutrophic waters, which can cause serious skin and eye irritation. In some areas of Serbia, the Danubian endemic familial nephropathy (also known as Balkan endemic nephropathy) occurs and is hypothesized to be linked to drinking-water quality (WHO, 2009).

Generally, watercourses in Serbia are polluted, and their quality is deteriorating. Most stretches of the Danube can be described as moderately polluted, but some tributaries and stretches of the lower Danube fail to achieve this status. In some areas harmful substances from farmland and heavy industries pollute the rivers and severely undermine the quality of the water (ICPDR, 2005; WHO, 2009; RHSS, 2010). Continuous monitoring of the régime, together with the determination of water quantity and quality, provides a relevant source of information in presenting the state of water resources in real time.

The Republic Hydrometeorological Service of Serbia (RHSS) undertakes systematic monitoring of quantitative and qualitative characteristics of the surface and ground water in order to determine, analyze and supervise the water régime on the territory of Serbia under the Waters Act and in compliance with the Regulation of the Systematic Waters Quality Testing passed by the Government of the Republic of Serbia (RHSS, 2010). According to the accepted methodology, the basic physic-chemical parameters are tested once a month. The additional physic-chemical parameters are determined at least four times a year, while metals and other harmful and dangerous substances are checked three to twelve times a year, depending on the economic importance of the given waterway. Total radioactivity is measured two to seven times a year in all more important profiles. The results of the established monitoring of the water quantity and quality are reflected in a significant number of data collected in the Hydrological Information System.

The aim of this study was to apply multicriteria PROMETHEE/GAIA method in order to perform the ranking of measuring points based on multiple criteria simultaneously, in terms of ten water quality parameters.

\section{EXPERIMENTAL}

\subsection{Sampling}

The investigation includes eight hydrological measuring stations (Figure 1) at distances given from the river mouth:

1. Bezdan $-1425.59 \mathrm{~km}$;

2. Bačka Palanka - 1298.6 km;

3. Novi Sad - 1254.98 km;

4. Zemun - $1174 \mathrm{~km}$;

5. Pančevo - 1154.6 km;

6. Beograd-Vinča $-1145,5 \mathrm{~km}$;

7. Tekija $-956.2 \mathrm{~km}$ and

8. Radujevac $-852 \mathrm{~km}$.

At the sampling point the water temperature, as well as $\mathrm{pH}$ value, were determined according to SRPS H.Z1.111 method, biochemical oxygen consumption (BOD-5) was determined by EPA 360.2 method, suspended solids according to 13.060.30 SRPS H.Z1.160 method, phosphates according to standard analytical method APHAS AWWA WEF 4500, total 
nitrogen oxides according to SRPS ISO 5664 method, while the estimated number of coliform bacteria (E. coli) per liter was determined 48 hours after incubation at $37^{\circ} \mathrm{C}$ (RHSS, 2010). water and they are used in WQI (Water Quality Index) methodology (Scottish Development Department, 1976) in determining the overall water quality of the surface water. Based on the use of standard

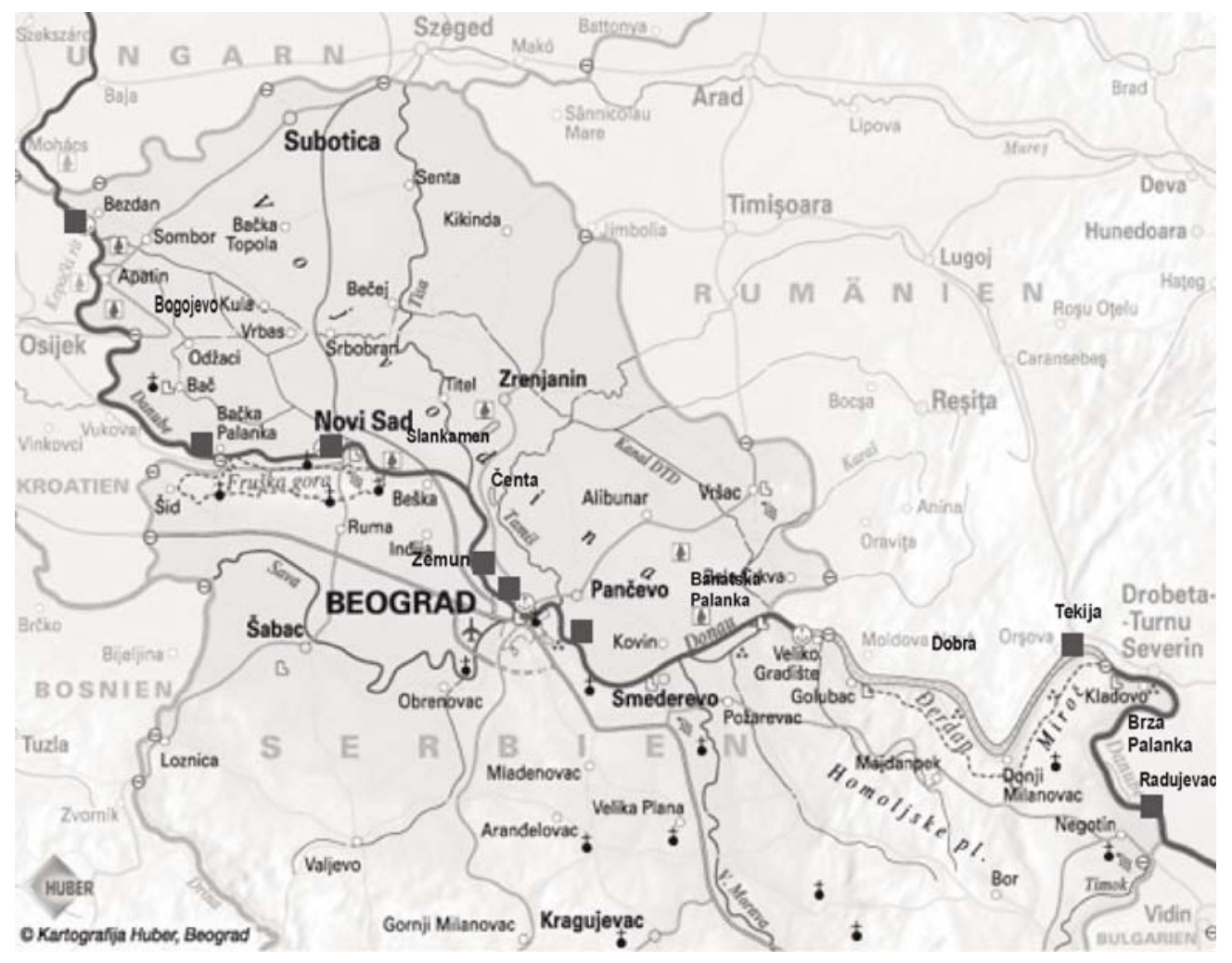

Figure 1. Measuring points on the Danube River in Serbia

\subsection{Data processing methodology}

For the purposes of ranking the selected measuring points in terms of water quality parameters multi-criteria decision-making (MCDM) method was applied, while ten water quality parameters were selected to be the ranking criteria: oxygen saturation, E.coli, BOD-5, pH value, total nitrogen oxides, orthophosphates, suspended matter, ammonium, temperature and conductivity. These parameters show physical, chemical and microbiological characteristics of the parameters for water characterization, the WQI sets the criteria for classification of surface water quality (Babović et al., 2011; Reza, \& Singh, 2010; Banerjee \& Srivastava, 2009; Sanchez et al., 2007; Kannel et al., 2007).

MCDM (DCLG, 2009) was widely used in analyzing the environmental pollution problems (Nikolić et al., 2010; Lim et al., 2005; Khalil et al., 2004). In this investigation the PROMETHEE method (Brans, 1982) was used for ranking of selected locations. Application of this particular method in processing the obtained 
results shows certain advantages compared to other MCDM methods such as easy way of problem structuring, huge amount of data to process, great possibilities of quantifying the quality values and fine software support (Nikolić et al., 2010; Nikolić, 2010; Macharis et al., 2004; Brans, 1982).

PROMETHEE represents an outranking method, for final set of alternatives (Nikolić et al., 2010; Nikolić, 2010; Brans et al., 1984). The key point in the application of this method is to define a corresponding function of preference and assign weight coefficient to each criterion. The preference function defines how a certain option is ranked in relation to another one and translates the deviation between two compared alternatives into a single parameter related to the preference level. The preference level represents an increasing function of deviation where, if the deviation is small, it relates to a weak preference while if the opposite is the case, i.e., if the deviation is large then it represents a strong preference of referent alternative (Brans et al., 1984; Macharis et al., 2004; Nikolić et al., 2010; Nikolić, 2010).

The PROMETHEE method is based on the determination of positive $\left(\Phi^{+}\right)$and negative flow $\left(\Phi^{-}\right)$for each alternative in relation to outranking relations and in accordance with obtained weight coefficient for each criterion attribute. Positive preference flow expresses how much a certain alternative dominates other alternatives, namely if the value is higher $\left(\Phi^{+} \rightarrow 1\right)$ the alternative is more significant. Negative preference flow expresses how much a certain alternative is preferred by other alternatives. The alternative is more significant if the value of outgoing flow is lower $\left(\Phi^{-} \rightarrow 0\right)$. Complete ranking
(PROMETHEE II) is based on the calculation of net flow $(\Phi)$, which represents the difference between the positive and the negative preference flow. The alternative with the highest value of net flow is then ranked best (Nikolić et al., 2010; Nikolić, 2010; Visual Decision Inc., 2007; Brans et al., 1984). Graphic interpretation of PROMETHEE method is provided by geometrical analysis for interactive assistance (GAIA) plane which gives a clear picture of the decision-making problem as it monitors PROMETHEE ranking (Visual Decision Inc., 2007).

PROMETHEE/GAIA method was applied using Decision Lab 2000 software package.

\section{RESULTS}

In this investigation ranking of eight selected locations depending on ten water quality parameters was conducted by using the PROMETHEE method. Oxygen saturation of water (O2 Saturation) is chosen to be a useful parameter because higher oxygen saturation contributes to better water quality and its content in water should be maximized (max), while other parameters need to be with lower share - minimized (min). To define the weight criteria, the fact that not all parameters have the same impact on water quality is taken into account, so the WQI share index of each parameter in the overall water quality index for the year 2010 . is used for such purposes. Table 1 shows results of the average yearly values of water quality parameters obtained on the selected measuring locations. Linear preference function was chosen as preference function for all of the criteria because of the parameters quantitative nature, with adopted 
Table 1. The Ranking Scenario

\begin{tabular}{|c|c|c|c|c|c|c|c|c|c|c|}
\hline & pH & $\begin{array}{c}\text { Conducti } \\
\text { vity }\end{array}$ & $\begin{array}{c}\mathrm{O}_{2}, \\
\text { Saturation }\end{array}$ & $\begin{array}{c}\text { Suspended } \\
\text { matter }\end{array}$ & BOD-5 & $\begin{array}{l}\text { Total } \\
\text { NO }_{2}\end{array}$ & $\begin{array}{c}\text { Orthoph } \\
\text { osphate }\end{array}$ & $\begin{array}{c}\text { Ammo } \\
\text { nium }\end{array}$ & $\begin{array}{c}\text { Temper } \\
\text { ature }\end{array}$ & E. coli \\
\hline Max/min & Min & Min & Max & Min & Min & Min & Min & Min & Min & Min \\
\hline Weight & 10.00 & 2.00 & 22.00 & 5.00 & 16.00 & 9.00 & 6.00 & 13.00 & 6.00 & 11.00 \\
\hline $\begin{array}{c}\text { Preference } \\
\text { function }\end{array}$ & Linear & Linear & Linear & Linear & Linear & Linear & Linear & Linear & Linear & Linear \\
\hline $\mathbf{Q}$ & 50 & $5 \%$ & $5 \%$ & $5 \%$ & $5 \%$ & $5 \%$ & $5 \%$ & $5 \%$ & $5 \%$ & $5 \%$ \\
\hline $\mathbf{P}$ & $30 \%$ & $30 \%$ & $30 \%$ & $30 \%$ & $30 \%$ & $30 \%$ & $30 \%$ & $30 \%$ & $30 \%$ & $30 \%$ \\
\hline Unit & $\mathrm{mg} / \mathrm{l}$ & $\mathrm{mg} / 1$ & $\mathrm{mg} / 1$ & $\mathrm{mg} / \mathrm{l}$ & $\mathrm{mg} / \mathrm{l}$ & $\mathrm{mg} / \mathrm{l}$ & $\mathrm{mg} / \mathrm{l}$ & $\mathrm{mg} / \mathrm{l}$ & $\mathrm{mg} / \mathrm{l}$ & $\mathrm{mg} / \mathrm{l}$ \\
\hline$\overline{\text { Bezdan }}$ & 8.3 & 470.7 & 98.10 & 30.9 & 2.00 & 1.070 & 0.046 & 0.06 & 12.2 & 8625 \\
\hline B. Palanka & 8.2 & 451.1 & 87.25 & 38.4 & 2.06 & 0.880 & 0.059 & 0.06 & 15.9 & 10533 \\
\hline N. Sad & 8.2 & 481.7 & 90.30 & 20.6 & 2.70 & 1.040 & 0.057 & 0.08 & 11.5 & 4633 \\
\hline Zemun & 7.9 & 413.6 & 90.70 & 23.2 & 2.10 & 0.300 & 0.043 & 0.11 & 14.2 & 1697 \\
\hline Pancevo & 8.1 & 457.6 & 82.20 & 52.4 & 2.10 & 0.710 & 0.070 & 0.08 & 13.1 & 24000 \\
\hline Beograd-V. & 7.9 & 395.0 & 87.80 & 20.0 & 1.92 & 0.310 & 0.045 & 0.08 & 14.6 & 1130 \\
\hline Tekija & 8.1 & 400.0 & 85.00 & 14.0 & 2.00 & 0.266 & 0.054 & 0.13 & 13.4 & 8550 \\
\hline Radujevac & 7.8 & 418.0 & 86.00 & 18.0 & 2.10 & 0.324 & 0.118 & 0.12 & 13.1 & 506 \\
\hline
\end{tabular}

thresholds of indifference and preference $(\mathrm{Q}$ and $\mathrm{P}$ ) in the zones of $5 \%$ and $30 \%$, respectively.

Based on data in Table 1 the values of positive $\left(\Phi^{+}\right)$and negative $\left(\Phi^{-}\right)$flows were obtained, as shown in Table 2.

PROMETHEE performed a complete ranking from the best to the worst location from the aspect of presence of harmful water quality parameters in the river on those locations, as shown in Figure 2.

The ranking results indicate that the best

Table 2. Preference flows

\begin{tabular}{lccc}
\hline \multirow{2}{*}{ Alternatives } & \multicolumn{3}{c}{ Preference flows } \\
\cline { 2 - 4 } Bezdan & 0.2707 & 0.1733 & 0.0975 \\
B. Palanka & 0.1650 & 0.2421 & -0.0771 \\
N. Sad & 0.1871 & 0.3070 & -0.1199 \\
Zemun & 0.2285 & 0.1551 & 0.0734 \\
Pancevo & 0.1182 & 0.3241 & -0.2060 \\
Beograd-V. & 0.2977 & 0.0814 & 0.2163 \\
Tekija & 0.1824 & 0.1994 & -0.0169 \\
Radujevac & 0.2192 & 0.1866 & 0.0326
\end{tabular}

water quality location on the Danube is the measuring point Beograd -Vinča, while the measuring point of Pančevo seems to be the most polluted location.

More precise view of the analysis results is obtained within GAIA plane. Considering that the value $\Delta$ (representing the measure of the quantity of information preserved by defined model) is satisfactory $(\Delta=71.89 \%)$, the validity of using this graphic tool in further presentation of the results is quite reasonable. In practice, the value of $\Delta$ is arround $60 \%$ and in most cases larger than 80\% (Brans et al., 1984).

The GAIA plane presents the projection of the set of $n$ alternatives that can be represented as a cloud of $n$ points in a $k$ dimensional space, where $n$ represents the number of alternatives and $k$ is the number of criterions. The basis of the position of criteria in GAIA plane (squares), concord, or conflict between certain criteria can be determined. Also, the positions of alternatives (triangles) determine strength or weakness of the properties of actions in regard to criteria - the closer to the direction 


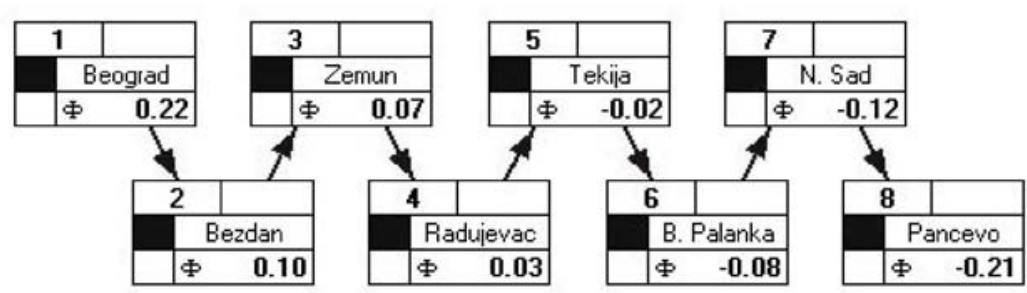

Figure 2. PROMETHEE II complete ranking of alternatives

of the criterion vectors the better alternative itself according to that criterion.

The coordinate axes, presented in Figure 3 , are assistive, dimensionless axes used for segmentation of the space in order to better present the strengths of the alternatives and criterions according to their position in the GAIA plane (Nikolić, 2010). Locations in Figure 3, gathered as Cluster 1 (Beograd, Zemun, Tekija and Radujevac) are good by a large number of criteria from which the location Beograd stands out as the closest one to the decision stick which defines a compromising solution in accordance to the given weights of the criteria, and with the lowest concentrations of harmful bacteria E.coli and nutrient Orthophosphates, required for the good water quality. On the contrary, within Cluster 2 of Figure 3, there are locations directed in the opposite direction of the decision stick pi (Pančevo, B. Palanka and Bezdan), with the largest percent of harmful water quality parameters, which evidently are not good according to

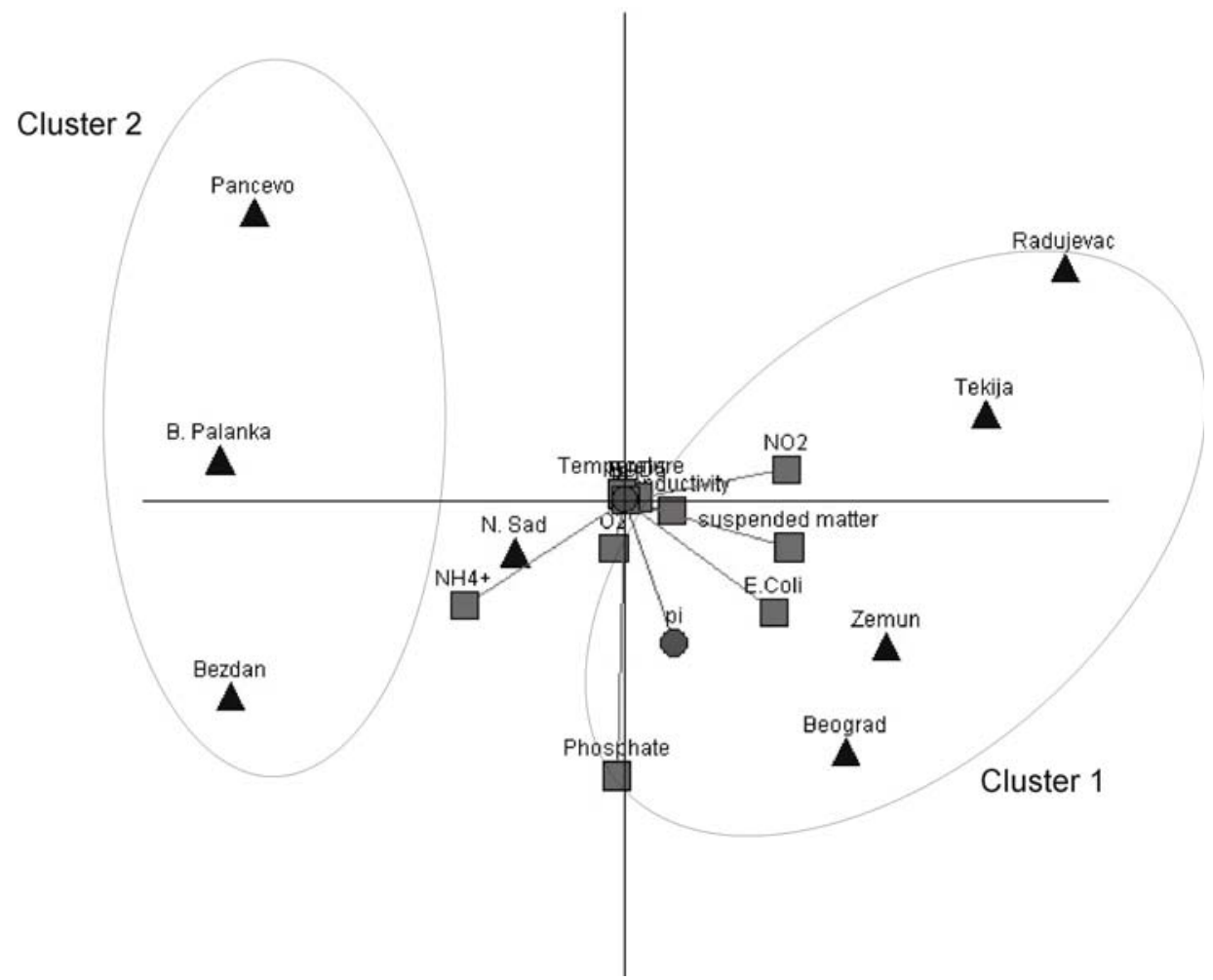

Figure 3. GAIA plane for the defined Scenario 
any criterion, and especially according to the Suspended matter, Total $\mathrm{NO}_{2}$, Orthophosphates and E.coli.

Parameters such as Temperature, $\mathrm{pH}$ and Conductivity are the criteria of the least impact on the ranking. They are located in the very beginning of the GAIA coordinate plane so that they are neutral.

\section{CONCLUSION}

Multicriteria analysis of the selected measuring points on the Danube, using water quality parameters, ranked locations from the best to the worst one, according to the quality of water. By using PROMETHEE/GAIA method, clusters with similar water quality of the Danube were obtained. These clusters identified locations Pančevo, B. Palanka and Bezdan as the most polluted spots on the Danube in Serbia. On the other hand, the analysis showed that the quality of the Danube in Belgrade (measuring location Beograd), the capital of Serbia, is satisfactory, and moreover the best in range. It is also evident that the water quality on the exit profile (Radujevac) is better than the quality of the water at the entrance profile (Bezdan).

The results obtained in this analysis could serve as a basis for the implementation of adequate measures in order to repair the main pollutants of the river, so that the quality of the Danube River could improve.

Acknowledgement: This work has been funded by the Serbian Ministry for Science under the projects No. III-43014 and TP 33034.

\title{
ВИШЕКРИТЕРИЈУМСКО РАНГИРАҢЕ КВАЛИТЕТА ВОДЕ ДУНАВА НА ТОКУ КРОЗ СРБИЈУ
}

\author{
Ивана Младеновић-Ранисављевића ${ }^{\mathrm{a}}$, Љиљана Такић ${ }^{\mathrm{a}}$, Милован Вуковићб \\ Ђорђе Николићб, Ненад Живковићщ, Пеђа МилосављевићД
}

\section{Извод}

У раду су приказани резултати вишекритеријумског рангирања квалитета воде реке Дунав дуж тока кроз Србију применом PROMETHEE/GAIA методе. Рангирање је извршено на основу вредности селектованих параметара квалитета воде измерених на осам мерних станица на реци Дунав у 2010-ој години. За параметре квалитета воде одабрано је десет параметара WQI (Water Quality Index) методе који показују физичке, хемијске и микробиолошке карактеристике воде за утврђивање сумарног квалитета воде. Резултати показују да је квалитет воде на излазном профилу из Србије бољи од квалитета воде на улазном профилу.

Кључне речи: Дунав, параметри квалитета воде, PROMETHEE/GAIA метода. 


\section{References}

Babović, N., Marković, D., Dimitrijević V., \& Marković, D. (2011). Some indicators of water quality of the Tamiš River. CI\&CEQ 17(1): 107-115.

Banerjee, T. \& Srivastava, R.K. (2009). Application of water quality index for assessment of surface water quality surrounding integrated industrial estatePantnagar. Water Science and Tehnology, 60 (8): 2041-2053.

Brans, J.P. (1982). L'ingénièrie de la décision; Elaboration d'instruments d'aide à la décision, La méthode PROMETHEE, in Nadeau, R., Landry, M. (Eds.), L'aide à la décision: Nature, Instruments et Perspectives d'Avenir, Presses de l'Université Laval, Québec, Canada, pp. 183-213.

Brans J.P., Mareschal B., \& Vincke Ph., (1984). PROMETHEE: A new family of outranking methods in multi-criteria analysis, in: Brans, J.P. (Ed.), Operational Research '84. North-Holland, Amsterdam, pp. 477-490.

DCLG (2009). Department for Communities and Local Government. Multicriteria analysis: a manual, Eland House, Bressenden Place, London, pp. 46.

ICPDR (2005). WFD Roof Report 2004 Document IC/084.

Kannel, P.R., Lee, S., Lee, Y.S., Kanel, S.R., \& Khan, S.P. (2007). Application of water quality indices and dissolved oxygen as indicators for river water classification and urban impact assessment. Environmental Monitoring and Assessment, 132(1-3): 93110.

Khalil, W.A-S., Goonetilleke, A., Kokot, S., \& Carroll, S. (2004). Use of chemometrics methods and multicriteria decision-making for site selection for sustainable on-site sewage effluent disposal.
Analytica Chimica Acta, 506(1): 41-56.

Lim, Mc.C.H., Ayoko, G.A., \& Morawska, L. (2005). Characterization of elemental and polycyclic aromatic hydrocarbon compositions of urban air in Brisbane. Atmospheric Environment, 39(3): 463-476.

Macharis C., Springael J., De Brucker K., \& Verbeke A. (2004). PROMETHEE and AHP: The design of operational synergies in multicriteria analysis. Strengthening PROMETHEE with ideas of AHP. European Journal of Operational Research 153(2): 307-317.

Nikolić, Đ. (2010). Multicriteria analysis of the pollutants distribution in the urban surroundings of copper smelters. PhD thesis. Technical faculty in Bor, Bor (in Serbian).

Nikolić, Đ., Milošević, N., Mihajlović, I., Živković, Ž., Tasić, V., Kovačević, R., \& Petrović, N. (2010). Multi-criteria analysis of air pollution with SO2 and PM10 in urban area around the copper smelter in Bor, Serbia. Water Air Soil Pollut., 206(1-4): 369-383.

Reza, R., \& Singh, G. (2010). Heavy metal contamination and its indexing approach for river water. International Journal of Environment Science and Technology, 7(4): 785-792.

RHSS (2010). Republic Hydrometeorological Service of Serbia, Report - 3. Water quality 2010, Belgrade (In Serbian).

Sanchez, E., Colmenarejo, M., Vicente, J., Rubio, A., Garcia, M., Travieso, L., \& Borja R. (2007). Use of the water quality index and dissolved oxygen deficit as simple indicators of watersheds pollution. Ecological Indicators 7(2): 315-328.

Scottish Development Department (1976). Development of a Water Quality Index. Engineering Division, Edinburgh. 
Visual Decision Inc., (2007). Getting Started Guide, Decision Lab 2000 Executive Edition, Montreal, Quebec, Canada.

WHO (2009). World Health Organization. Environment and Health performance review, Serbia. WHO Regional Office for Europe, Denmark, pp. 11. 